\title{
КЛІНІЧНИЙ ВИПАДОК УСПІШНОГО ХІРУРГІЧНОГО ЛІКУВАННЯ ПІДГОСТОРОЇ ЕПІДУРАЛЬНОЇ ГЕМАТОМИ ПОТИЛИЧНОЇ ДОЛІ ТА ЗАДНЬОЇ ЧЕРЕПНОЇ ЯМИ
}

\section{THE CLINICAL CASE OF SURGICAL TREATMENT PARIETAL AND POSTERIOR FOSSA EPIDURAL HEMATOMA}

\author{
I.C. Богдан (I.S. Bogdan) ${ }^{1}$, I.M. Рацин (I.M. Ratcyn) ${ }^{2}$, Б.В Бондарчук (B.V. \\ Bondarchuk) ${ }^{2}$, В.В. Циснецький (V.V. Cysnetsky), O.A. Ковалишин (O.A. \\ Kovalishin) \\ ${ }^{1}$ Військовий медичний центр Західного регіону Міністерства Оборони України, \\ Львів, Україна \\ 2 Львівська клінічна лікарня на залізничному транспорті, Львів, Україна
}

Abstract. A case of surgical treatment
of the patient with parietal and occipital
fossa epidural hematoma is presented.
X-ray examination didn't reveal a
fracture of paretal os. MRI diagnosed
parietal and posterior fossa epidural
hematoma. During the craniectomy
realived fracrure of the parietal os,

epidural hematoma removed. The souse of the bleeding was veinsperforates of the skill. A dynamic MRI found a positive outcome. The parient withdraw on the 10 day after operation. Keywords: epidural hematoma, posterior cranial fossa, surgical treatment.

Вступ. Травматичне ураження задньої черепної ямки (ЗЧЯ) являється одним 3 найбільш важких видів черепно-мозкової травми. Їх особливість та важкість обумовлені складністю клінічної діагностики та високою летальністю. До появи КТ/МРТ летальність при важкій травмі ЗЧЯ наближалась до $100 \%$. Описувались одиничні спостереження позитивних випадків при важкій черепно- мозковій травмі ЗЧЯ $(1,4)$.

Серед травматичної патології утворів ЗЧЯ найбільш частіше зустрічаютьсяч епідуральні гематоми (ЕДГ), які становлять 4-12,9\% від всіх ЕДГ и 20-64\% від всіх уражень ЗЧЯ $(1,2)$. У більшості випадків епідуральні гематоми ЗЧЯ знаходяться над одною півкулею мозочку, дуже рідко над двома півкулями мозочку. У $35-66 \%$ випадків ЕДГ розповсюджуються супратенторіально на задню поверхню потиличних та скроневих долей, відтискуючи поперековий синус та місце відтоку синусів. Джерелом кровотечі гематоми ЗЧЯ являються судини пошкодженої твердої мозкової оболонки, впадаючі вени в поперековий синус, вени, які перетинають епідуральну щілину. Невеликий діаметр судин i, як правило, венозний характер кровотечі обумовлюють підгострий перебіг захворювання у більшості випадків. Більш значний по об'єму супрасубтенторіальні гематоми формуються у тих випадках, коли джерелом кровотечі являється поперековий синус та артерії твердої мозкової оболонки, які знаходяться супратенторіально $(2,4)$.

3 появою нових методів візуалізації - комп'ютерної (КТ) та магнітнорезонансної (МРТ) томографії діагностика уражень ЗЧЯ значно покращилась, 
появилась можливість визначити кількісні характеристики ураження, стан навколишніх структур головного мозку, динамічного спостереження за патологічним процесом. Цим пояснюється збільшенням долі прижиттєвої діагностики травматичних уражень ЗЧЯ в структурі черепно-мозкової травми ЧМТ), яка становить 0,1\%-0,3\%. Серед хворих, оперованих 3 приводу ЧМТ, на їх долю приходиться 1,1\%-6,5\% $(1,3)$.

Рідкість даної патології перешкоджає правильній діагностиці та проведенню своєчасного оперативного лікування.

\section{Приводимо власне клінічне спостереження.}

Хвора К., 1957 року народження, поступила у нейрохірургічне відділення зі скаргами на сильні головні болі, головокружіння, шаткість ходи.

Зі слів хворої 4 дні тому біля 19 години вдома, під час ремонтних робіт, переходячи через поріг впала, вдарилась потилицею об бетонну підлогу. Свідомість втрачала на декілька секунд. Після травми у хворої була блювота. Через два дні оглянута невропатологом, проведено краніографію у 2-х проекціях, при якій кістково-травматичних змін черепа не виявлено. Скерована на стаціонарне лікування у нейрохірургічне відділення.

Об’єктивно: Загальний стан хворої важкий. Правильної тілобудови, пониженого відживлення. Шкірні покриви та видимі слизові оболонки чисті, бліді. В легенях ослаблене везикулярне дихання, хрипів не має. Серцеві тони ритмічні. Пульс - 60 уд/хв. АТ - 170/100 мм. рт. ст. Язик вологий. Живіт при пальпації м'який, не болючий. Печінка не збільшена. Функції тазових органів контролює.

Неврологічно: ШКГ 14. Загальмована, орієнтована. Зіниці $\mathrm{D}=\mathrm{S}$, Конвергенція дещо ослаблена. Крупнорозмашистий ністагм при погляді вправо. Обличчя симетричне. Язик відхиляється вліво. Активні рухи в руках та ногах збережені, м'язова сила у кінцівках достатня. Сухожилкові та периостальні рефлекси на верхніх та нижніх кінцівках живі, одинакові з обох сторін.

Виявлено менінгеальні симтоми - ригідність потиличних мязів , симптом

Бабінського справа. В позі Ромберга стояти не може. Локально: забій м'яких тканин потиличної ділянки справа.

Загальний аналіз крові: еритроцити - 4,6 Т/л, гемоглобін - 124 г/л, колірний показник - 0,9; лейкоцити - 8,9 Г/л, паличкоядерні нейтрофіли - 6\%, сегментоядерні - 62\%, еозинофіли - 2\%, лімфоцити $-21 \%$, моноцити - 9\%, ШОЕ - 3 мм/год. Загальний аналіз сечі: реакція кисла, питома вага 1010,

білок, цукор - не має, лейкоцити 2-4 в п/3., еритроцити (змінені) - 1-2 в полі зору. Кров на RW від'ємна. Біохімічний аналіз крові: сечовина - 6,1 ммоль/л, креатинін - 102 ммоль/л, білірубін загальний - 21,6 мкмоль/л, прямий - 13,6; кальцій - 2,0 ммоль/л, АЛТ - 0,5 ммоль/год.л, АСТ - 0,4 ммоль/год.л., альфаамілаза - 17 г/год.л. Глюкоза у крові 4.6 ммоль/л.

Аналіз сечі на етанол - від'ємний

ЕКГ: синусовий ритм 3 частотою серцевих скорочень 60 в 1 хв. Горизонтальне положення електричної осі серця. Ознаки ваготонії. Часті шлуночкові екстрасистоли. Ознаки ішемії задньо-діафрагмальної стінки гіпертрофованого лівого шлуночка. 
$\mathrm{R}$-графія органів грудної клітини - легені та серце - вікові зміни Терапевт: скарги на головну біль, нудоту, блювоту. Шкірні покрови звичайної окраси, пониженого відживлення. В легенях перкуторний звук, аускульптативно дихання везикулярне, хрипів не має. Тони серця приглухуваті, ритм правильний. Екстрасиситола клінічно не фіксується. АТ - 170/100 мм.рт.ст. пульс - 78 ударів в хвилину. Живіт м'який, не болючий. Печінка та селезінка не побільшені. Набряків не має.

Діагноз: Артеріальна гіпертензія II ступеня 2 степені, високий кардіоваскулярний ризик. IXC: атеросклеротичний кардіосклероз, транзиторна шлуночкова екстрасистолія. Н - I ст.

На х-променевих краніограмах: Ознаки інтракраніальної гіпертензії, кістоково- травматичних змін не виявлено.

МРТ головного мозку: Позаду правої потиличної долі та позаду правої гемісфери мозочка візуалізується епідуральна гематома, ізоінтенсивного сигналу в Т1 33 з гіперіненсивними вкрапленнями по обідку, гіперінтенсивного сигналу в T2 33, в T2 GRE з гіпоінтенсвним обідком гемосидерину, розміром 92x45x30 мм. Візуалізується компресія стовбуру мозку, правої гемісфери мозочка та правої потиличної долі. IV шлуночок компресований. За розміром епідуральна гематома в проекції лівої лобної ділянки, розміром до 30 х 8 мм 3 компресією лівої лобної долі. Не виключено наявність крові в субарахноїдальних просторах, бороздах лівої лобної долі та правої потиличної долі. Невелика субдуральна гематома довкола правої півкулі мозку. Шлуночки мозку, субарахноїдальні простори вільні, не поширені. Заключення: у хворої епідуральна гематома позаду потиличної долі та мозочка, в лівій лобній ділянці. Плащевидна судбуральна гематома. Субарахноїдальний крововилив.

В результаті анамнезу, загально соматичного та неврологічного огляду, даних рентгенографії черепа у двох проекціях, даних МРТ головного мозку хворій встановлено діагноз:

Важка закрита ЧМТ: Забій головного мозку важкогоступеня. Підгостра епідуральна гематома правої потиличної долі та мозочка, в лівій лобній ділянці. Правобічна плащевидна субдуральна гематома. Субарахноїдальний крововилив.

II. Дислокаційний синдром. Компресія стовбуру мозку.

III. Артеріальна гіпертензія II ступеня, високий кардіоваскулярний ризик. Ішниічна хвороба серця: атеросклеротичний кардіосклероз.

Хворій проведена операція: декомпресивна трепанація черепа у правій потиличній ділянці, видалення гострої епідуральної гематоми .

Ендотрахеальний наркоз. Положення хворої на лівому боці. В правій потиличній ділянці забійна рана неправильної форми. Після чотирикратної обробки шкірних покривів операційного поля розчином йоданату, проведено лінійний розріз м'яких тканин у правій потиличній ділянці до першого шийного хребця. М'які тканини імбібовані кров'ю. Після видалення надкісниці виявлено лінійний перелом потиличної кістки 3 переходом на основу черепа. За допомогою фрезевого отвору та скушуванням зроблено кістковий отвір округлої форми діаметром біля 6,0 cм. В рану стали виділятись згустки крові. 
Об'єм гематоми біля 50 см3. Після видалення гематоми появилась пульсація мозку.

Проведено ретельний гемостаз. Ревізія рани на сторонне тіло. Встановлено гемостатичну серветку «Тахокомб» в ложе гематоми. Встановлено резиновий випускник в підшкірний простір. Пошарові шви на м'ягкі тканини. Йод, асептична пов'язка.

Післяопераційний діагноз: Підгостра епідуральна гематома потиличної долі 3 переходом у задню черепну ямку.

Хворій проведено лікування: офрамакс 1,0 внутрішньовенно-крапельно на 100,0 фізіологічного розчину 2 р. на день - № 6; розчин дексаметазону 4 мг 2 $\mathrm{p}$ на день №6 дом’язево, розчин етамзилату 12,5\% - 2,0 дом'язево №6, вітамінотерапія (нервіплекс), таблетки Фінлепсин 100 мг х 2p. денно, седативна терапія (таблетки сібазона 1 таблетка на ніч), шоденні перевязки рани.

Після лікування стан хворої покращився. У неврологічному статусі: В свідомості, орієнтована. Менінгеальних симптомів не має. Зіниці, очні щілини $\mathrm{S}=\mathrm{D}$. Фотореакції мляві. Конвергенція послаблена. Горизонтальний ністагм при погляді в сторони. Погляд фіксує. Обличчя симетричне. Язик по середній лінії. Сухожилкові та периостальні рефлекси рівномірно пригнічені. Чутливість на обличчі, кінцівках - збережена. Патологічних стопних симптомів не виявлено. В позі Ромберга киливається, пальце-носову пробу виконує задовільно з обох сторін.

Післяопераційна рана загоїлась первинним натягом, знято усі шви.

МРТ головного мозку (контроль через 10 днів) - в порівнянні 3 попереднім (доопераційним МРТ) візуалізується позитивна МРТ динаміка. Епідуральна гемтома в проекції правої лобної частки зменшилась в розмірі - 2 мм х 2 мм, сигнал гіперіненсивний в Т1 33. Значно менша на розміром епідуральна гематома позаду правої потиличної долі та позаду правої гемісфери мозочку, максимальна товщиною товщиною до 7 мм. Кров субдурально справа та в субарахноїдальних просторах не візуалізується. Решта мозку - супра - та інратенторіально - без ознак компресії, вогнищевих змін не має. Серединні структури без зміщення.

Заключення: позитивна динаміка. Залишки епідуральної гематоми в лівій лобній ділянці та в задній черепній ямі справа.

Хвора була виписана додому під нагляд невропатолога з рекомендацією постіний прийом фінлепсина 200 мг двічі на день на протязі 3 місяців.

\section{Висновки.}

1. Особливістю клінічного перебігу травми ЗЧЯ явилось поєднання мозочкової, загальномозкової та дислокаційно-стовбурової симптоматики.

2. Неврологічні синдроми ураження ЗЧЯ при відсутності рентгенологічних признаків перелому в ділянці ЗЧЯ $є$ обов'язковим показанням для термінового КТ/МРТ обстеження хворого 3 метою виключення внутрішньочерепної гематоми.

3. Своєчасна проведена операція здатна забезпечити успіх лікування до появи вторинно - дислокаційних ускладнень. 


\section{Список літератури.}

1. Zotov Ju.V., Shhedrenok V.V. Hirurgija travmaticheskih vnutrichepnyh gematom i ochagov razmozhzhenija golovnogo mozga. -L.: Medicina 1984. 209 s.

2. Pedachenko E.G., Kadzhaja N.V. Travmaticheskie vnutricherepnye gematomy redkoj lokalizacii. - K.:Zdorov'ja, 1995. $88 \mathrm{~s}$.

3. Roda J.M., Gimenez D., Perez-Higueras e.a. Posterior fossa epidural hematoma: a review and synthesis // Surg. Neuorol. -1983. V. 19. -P. 419-424.

4. Servedei F., Facconi G., Rocuellar P e.a. Asymptomatic extradural hematomas: Results of multicenter study of 158 cases a minor-head injury // Acta neurochir. 1989. V.96, \#1-2. -P. 39-45. 


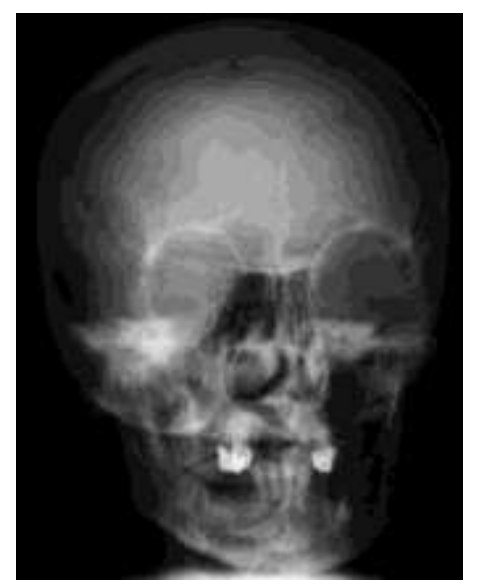

Мал. 1. Фасна краніограма операції:

кістково-травматичних змін немає

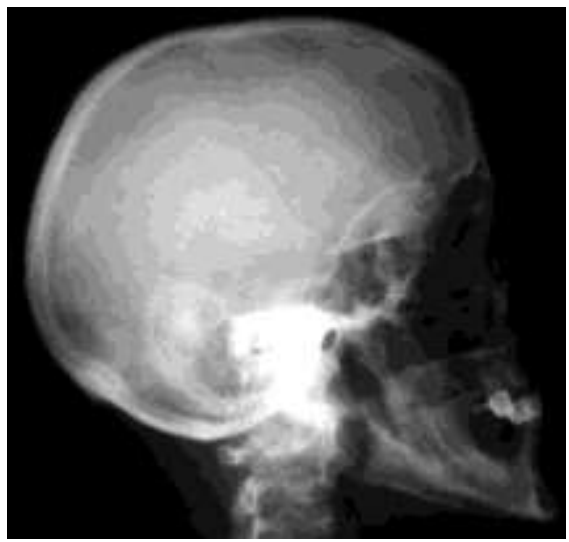

Мал. 2. Бокова

до

краніограма до операції: кістково-травматичних Змін немає

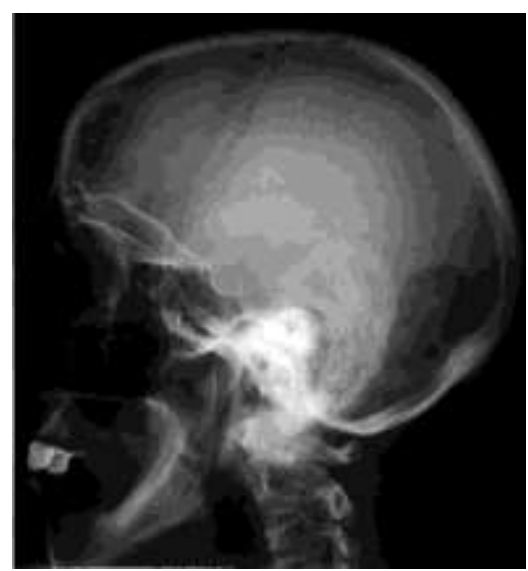

Мал. 3. Бокова

краніограма після операції: дефект потиличної кістки $3,0 \times 4.5 \mathrm{~cm}$.

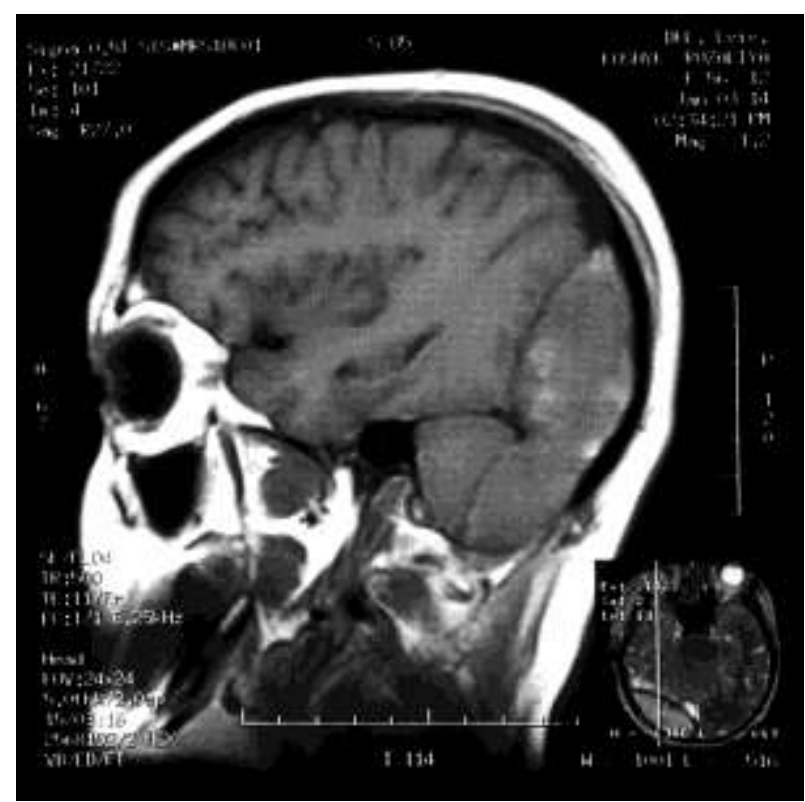

Мал. 4. МРТ до операції (сагітальний зріз):

епідуральна гематома потиличної ділянки та над гемісферою мозочка

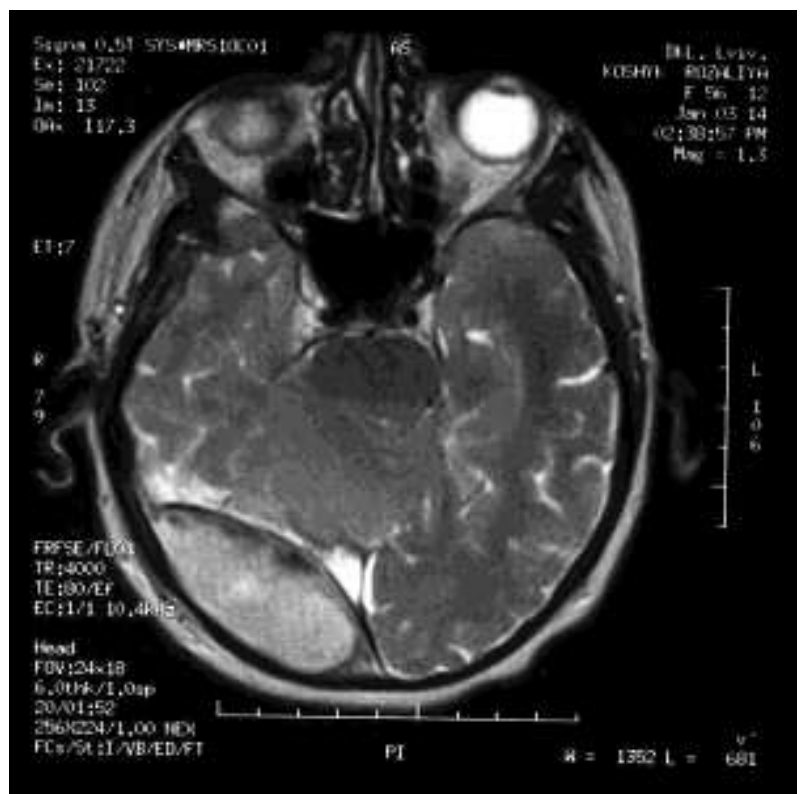

Мал. 5. МРТ до операції (аксіальний зріз):

епідуральна гематома правої гемісфери мозочку 


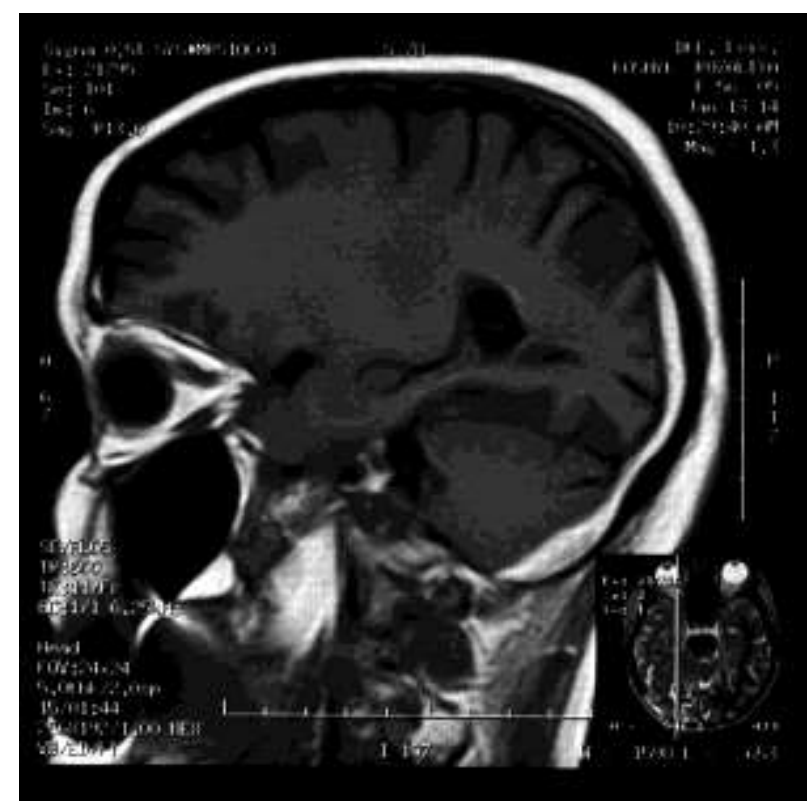

Мал. 6. МРТ після операції: (сагітальний зріз): залишки епідуральної гематоми потиличної ділянки та над гемісферою мозочка

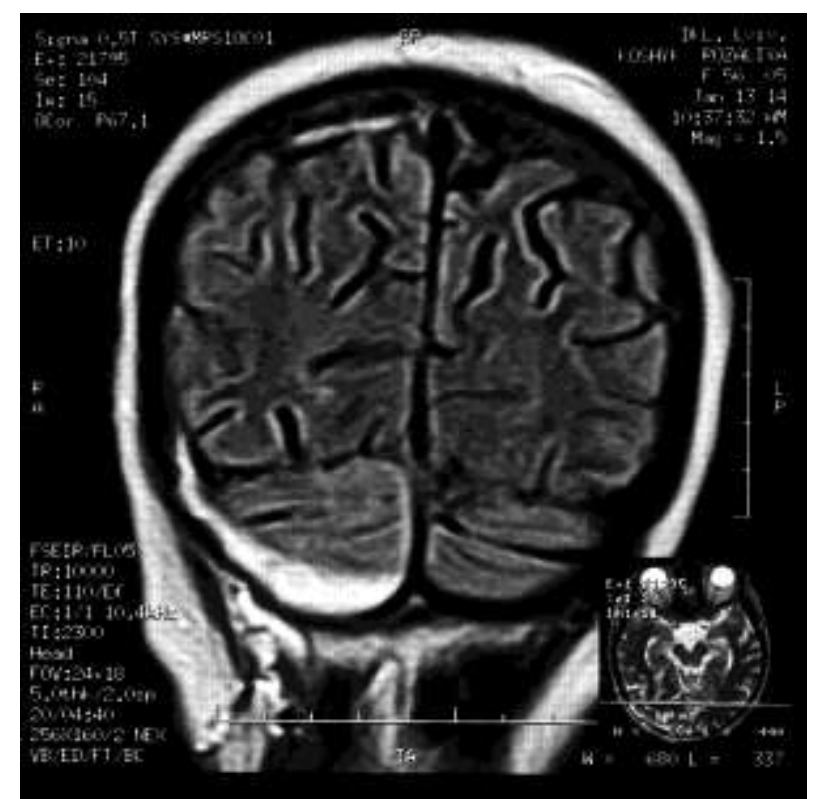

Мал. 7. МРТ після операції:

(аксіальний зріз):

залишки епідуральної гематоми потиличної ділянки та над гемісферою мозочка 